\title{
УСВІДОМЛЕННЯ ПОМИЛОК ХУДОЖНІХ ПЕРСОНАЖІВ ЯК ШЛЯХ ДО САМОВДОСКОНАЛЕННЯ УЧНІВ
}

\section{Бутурлим Тетяна Іванівна}

Кандидат педагогічних наук, спещіаліст вищої категорії, учитель української мови та літератури Ніжинського обласного педагогічного ліцею Чернігівської обласної ради, м. Ніжин (Украӥна)

\begin{abstract}
Анотація. У статті актуалізується проблема необхідності усвідомлення помилок персонажів художніх творів як шлях до самопізнання, самовдосконалення особистості. Наголошено на важливості здійснювати рефлексію власних дій, думок, емоційних станів. Проаналізовано поняття «помилка». Наведено класифікаџію помилок 3. Партико: інформаційні, модальні, фактичні, темпоральні, локальні, ситуативні, семіотичні (відображувальні, значеннєві, тезаурусні), сприйняттєві, атенційні, копіювальні. Проаналізовано зміст поняття «психологічна помилка» (свідомі чи безсвідомі думки, почуття, дї, щзо порушують усталений гармонійний зв'язок із власним «Я» та світом, зумовлюють глибокі душевні страждання, внутрішні). Наведено приклади із програмових творів украӥнської літератури 10 класу: визначено, що саме неправильно зробили персонажі, окреслено орієнтовні иляхи вдосконалення поведінки. Проаналізовано помилки таких художніх образів: Марусі й Омелька («Кайдашева сім'я» I. НечуяЛевицького), Чіпки («Хіба ревуть воли, як ясла повні?» Панаса Мирного та Івана Білика), Мартина («Мартин Боруля» Івана Карпенка-Карого), Докії («Каторжна» Б. Грінченка), Мойсей («Мойсей» I. Франка), Хома («Сойчине крило» І. Франка), головного героя («Intermеzzо» М. Кочюбинського), Івана («Тіні забутих предків» М. Кочюбинського), Сави («Земля» О. Кобилянської), Івана («Камінний хрест» В. Стефаника), Лукаша («Лісова пісня» Лесі Українки), головного героя («Момент» В. Винниченка). Визначено, як неконструктивні риси характеру, поведінка, цүіннісні орієнтаџіï позначаються на життєвому сценарії персонажів. Установлено взаємозв 'язок між можливістю персонажа та учня зробити крок до саморозвитку иляхом усвідомлення й корекції помилок.
\end{abstract}

Ключові слова: рефлексія, помилки, художні персонажі, усвідомлення проблеми, самовдосконалення.

Постановка проблеми у загальному вигляді та її зв'язок із важливими наукови- ми чи практичними завданнями. Важливою умовою самовдосконалення особистості є ус- 
відомлення власних, помилок, корекція цінностей, думок, висловлювань, учинків. Це сприяє розвитку особистісної рефлексії (саморефлексії). Пізнання людини власного внутрішнього світу, оцінка своїх якостей і станів призводить до поступальних змін і породжує новоутворення. На думку Н. Гуткіної, рефлексія - це механізм самосвідомості, особливий акт самодослідження, проявом якого $\epsilon$ рефлексивні очікування, критерієм наявності - рефлексивний самоаналіз, що призводить до нових знань про себе. За умови позитивного ставлення до власного «Я», коли особистість приймає себе й переживає це ставлення як цінність, рефлексія сприяє саморозвитку. Деструктивна - негативно позначається на самопочутті людини, зумовлює появу помилок свідомого й несвідомого характеру.

Аналіз останніх досліджень і публікацій. Проблема організації самостійної роботи над помилками висвітлено в роботах Е. Божовича, В. Зарецького, Н. Гуткіної С. Крамера, С. Манвелова, В. Степанського, О. Юдіна та інших.

Виділення невирішених раніше частин загальної проблеми. Тому дуже важливо спонукати учнів до усвідомлення власних помилок, попереджати небажані психологічні стани, а в разі їх виникнення - досягнути компромісу із власним «Я» та оточуючими. Навіть якщо вони сприймають навчальний матеріал, необхідно спонукати до свідомого осмислення тексту з метою отримання конс- труктивного життєвого досвіду, щоб не повторити помилок художніх персонажів у реальній ситуації.

Мета статті - осмислити проблему впливу читання й інтерпретації художніх творів на самосвідомість старшокласників, свідомого формування конструктивної рефлексії.

\section{Виклад основного матеріалу дослі-} дження. «Ніщо так не навчає, як усвідомлення своєї помилки. Це один із головних засобів самовиховання», - зазначав Т. Карлейль. В «Академічному тлумачному словнику» помилка розглядається як неправильність у підрахунках, написанні слова; неточність у якомунебудь механізмі, пристрої, схемі, карті; неправильність у вчинках, діях; неправильна думка, хибне уявлення про когось, щось [5]. Класифікація помилок осмислена 3. Партико в праці «Загальне редагування» [4]. Автор виділяє такі типи помилок: інформащійні (відсутність новизни, повторення викладеного матеріалу, опис очевидного), модальні (неправильне враховування відношення матеріалу до дійсності), фактичні (хибність висловлювань), темпоральні (неправильно зазначений час подій), локальні (неточності зображення місця подій), ситуативні (відхилення від ситуації, описуваної в тексті), семіотичні (кодувальні (відхилення від норми коду), відображувальні (змалювання відмінного від авторського варіанту зображення образу), значеннєві (неправильне слововживання)), тезаурусні (помилки стосовно певної 
групи реципієнтів), сприйняттєві (помилки, пов'язані зі сприйманням повідомлення, що призводить до двозначності), атенційні (помилки, пов'язані з переключенням реципієнтами уваги на інші об'єкти), копіювальні (помилки, що виникають при друці матеріалу). У статті ж ітиметься про психологічну помилку. Це поняття ми розуміємо як свідомі чи безсвідомі думки, почуття, дії, щуо порущують усталений гармонійний зв'язок із власним «Я» та світом, зумовлюють глибокі душевні страждання, внутрішні конфлікти, девіаціï. Важливо зрозуміти свою роль у проблемі, що виникла, проявити активність із метою іiї розв'язання, досягнення внутрішньої і зовнішньої стабільності.

Наведемо приклад, які орієнтовні висновки мають зробити учні 10 класу в процесі прочитання й інтерпретації художніх творів, де персонажі припустилися ряду помилок.

\section{«Кайдашева сім'я»}

\section{Івана Нечуя-Левицького}

Помилка Mapyci Кайдашихи в тому, що вона зверхньо ставилася до чоловіка, не цінувала його тяжкої праці, своїми сварками підштовхнула Омелька на шлях моральної деградації, принижувала його чоловічу гідність, самостійно розпоряджаючись сімейним бюджетом, приймаючи рішення, не порадившись 3 ним та дітьми. Також не приділяла належної уваги синам, Карпові та Лаврінові: не обговорювала 3 ними їхні проблеми, переживання, життєві цілі, навпаки - конфліктуючи 3 невістками, виявляла неповагу до їхнього вибору супутниці життя, відчужувала від себе власних дітей. Якби Кайдашиха не була такою егоїстичною, то підтримувала б Карпа й Лавріна в усіх їхніх починаннях, раділа, що має невісток, онуків, допомогла їм реалізуватися як самодостатнім господарям. Помилка Омелька Кайдаша в тому, що він не відстояв власне право бути головою родини в патріархальній сім’ї, піддався впливу владної дружини, опустив руки i, замість того, щоб боротися за сімейне щастя, морально деградував (приглушував душевний біль із допомогою спиртного). Він не зумів учасно зупинитися: поодиноке вживання оковитої переросло в алкоголізм, що призвело до появи галюцинацій та абсурдної смерті (утопився в річці). Омелько не скористався шансом стати заможнім хазяїном (адже був колись гарним стельмахом), якого б поважали односельці, сини, дружина, невістки, онуки. Не знайшов спільної мови і $з$ дітьми (як результат гіпоопіки): сини не поважали його думки, принижували його, а Карпо навіть підняв на нього руку.

\section{«Хіба ревуть воли, як ясла повні?»}

\section{Панаса Мирного та Івана Білика}

Помилка Чіпки в тому, що він став жертвою власної концепції «правди». Усе життя прагнув подолати соціальну маргінальність, але зустрічав опір із боку оточуючих. Намагаючись відстояти соціальну справедливість у суспільстві, Чіпка не змінив себе, а звинувачував у всьому владу, яка грунтувалася на брех- 
ні, корупції, пригніченні прав нижчих верств населення. Він міг би бути високоповажним хазяїном, гарним сім'янином, адже йому Бог дав працездатність, цілеспрямованість, наполегливість та прекрасну дружину Галю. Проте Чіпка не скористався цим шансом - і в результаті став жорстоким мстителем, грабіжником, убивцею, агресором, пиякою. Він не міг пробачити всі обра́зи, які завдали йому в дитинстві, не змирився і з тим, що в ньому забрали землю. Ненависть до панів спроектувалась на всіх простих людей, що не визнавали його філософії «правди». Не усвідомив, якого лиха накоїв: убив козацьку родину, завдав душевної травми матері й дружині, яка не витримала всього цього й повісилася. Страшно те, що Чіпка не кається навіть тоді, коли його засилають на каторгу, навпаки - планує в майбутньому помститися за те, що його заслали до Сибіру.

\section{«Мартин Боруля"}

\section{Івана Карпенка-Карого}

Помилка Мартина полягає в тому, що він, прагнучи досягти дворянського титулу, визнання в соціумі, ігнорує потреби й інтереси власної сім'ї, утрачає духовні цінності у взаєминах із Марисею, робітниками, кумом. Заради того, щоб стати вищим на одну соціальну сходинку, намагається видати дочку заміж за «благородного чоловіка», пихатого Націєвського, а не за Миколу, якого щиро кохала. Помилковим було рішення Мартина судитися 3 дворянином Красовським, який його, шляхтича, назвав «бидлом», а сина «телям»: той помстився - поставив до відома, що виганяє їхню сім’ю із села. Добре, що після духовної поразки - нездійсненні намірів стати дворянином - Мартин усвідомлює свою помилку, тому відновлює давні мужицькі порядки в домі, благословляє Марисю та Миколу на щасливе сімейне життя, мириться 3 кумом Гервасієм.

\section{«Каторжна» Бориса Грінченка}

Помилка Докії полягає в тому, що вона ні 3 ким не ділилася власними переживаннями, не відстоювала свої права, а терпіла агресію п'яного батька, знущання й приниження мачухи та їі дітей, обра́зи ровесників, зраду коханого Семена. Увесь негатив накопичився й вивільнився в деструктивній формі - спробі підпалити повітку хатини, де відбувалися вечорниці. Та постраждала сама: померла від опіків. Проте в смерті винна не стільки Докія, скільки соціум: батько, який не підтримав дочку після смерті матері, не звертав на неї уваги, одружившись з іншою жінкою, був на стороні дружини в прагненні принизити, образити іiі; мачуха, яка здійснювала фізичне й психічне насильство над нею (била, тягала за волосся, зрубала калину, якій дівчинка розказувала про свої страждання, не купувала одягу, налаштовувала власних дітей про неї); молодь, що глузувала 3 неї, прозивала «каторжною»; Семен, який посміявся 3 неї, зрадивши з Пріською.

«Мойсей» Івана Франка 
Помилка Мойсея в його слабкодухості. Тривалий час, 40 р., він користувався авторитетом, довірою у єврейського народу, був вождем у пошуках обітованої землі. Однак не зумів протистояти натовпу, який вигнав його 3 табору, психологічно зламався. У душі зародилися сумніви щодо правильності виконання обов'язку. За це Сгова покарав Мойсея: пророкує побачити обіцяний край, але не ввійти в нього, померти на порозі нового життя. Він мав виконати свою місію до кінця, а не зупинятися на півшляху, бути більш упевненим у собі, підтримати віру єврейського народу в побудові кращого життя, допомогти їм усвідомити аморальність намірів Датана й Авірона, які пропонують закидати пророка камінням, закликають поклонятися іншим богам (Ваалу й Астарті).

\section{"Сойчине крило» Івана Франка}

Помилка Хоми (Массіно) полягає в тому, що він живе у своєму закмненому внутрішньому світі й не впускає туди інших, так само не здатний зрозуміти бажань, потреб, інтересів, почуттів інших. Після втечі коханої Маpiї (Манюсі) з першим-ліпшим чужим чоловіком не може збагнути мотивації іï вчинків, не здатний усвідомити власну помилку, тому занурюється в егоїстичне самозакохане життя, переконуючи себе, що йому добре самому. Лише глибока сповідь Марії в листі допомогла зрозуміти, що потрібно впустити у свій світ близьких йому людей, а за власне щастя варто боротися. Тоді Хома не скористався своїм шансом, зараз же, після повернення коханої, обов'язково ним скористається.

\section{«Intermezzо» Михайла Коцюбинського}

Помилка головного героя полягає втому, що він тривалий час накопичував у собі негативні емоції, не намагався подолати внутрішній конфлікт, досить чутливо реагував на суспільні події. Це зумовило появу гострої депресії. Добре, що в потрібний момент інтелектуал-митець прийняв рішення - відпочити в селі, розібратися в собі, досягти внутрішньої гармонії. Але й там поводить себе насторожено: ще довго відходить від «залізної руки міста» (пекла громадських обов'язків і незліченних «треба, мерзенних вчинків людей, бруду їхнього існування, соціальної несправедливості), нікого до себе не підпускаючи. Поступово його душа зцілюється завдяки природі (ниві, зозулі, жайворонкам, сонцю) - тепер він здатний сприймати людське горе, готовий повернутися в місто, творити на благо народу.

\section{"Тіні забутих предків"}

\section{Михайла Коцюбинського}

Помилка Івана в тому, що він не зумів подолати депресію, утративши кохану Марічку. Потрібно було відпустити іï, розпочати нове життя, спрямовуючи енергію на роботу, спілкування з друзями тощо. Не доцільно було одружуватися з Палагною тільки тому, що цього хотіли оточуючі. Помилкою було й те, що не проявляв уваги до дружини, згадував про Марічку в іiі присутності, був пасивним, неговірким, емоційно холодним. Проявляв 
байдужість, коли привселюдно Палагна зраджувала $з$ Юрою, не захищав свою чоловічу честь, а став посміховиськом для всього села. Тому лише після смерті головний герой віднайшов душевний спокій, оскільки зустрівся 3 тією, котру любив більше за життя.

\section{«Земля» Ольги Кобилянської}

Помилка Сави полягає в тому, що він вороже налаштований до оточуючих, навіть до рідних людей, ревниво ставиться до Михайла, якого, на його думку, батьки люблять більше. Не потрібно було бунтувати, а допомагати родичам по займатися сільським господарством, щоб ті могли ним пишатися. У прагненні досягти абсолютної свободи Сава втрачає духовні цінності, сприймає людей як зло, котре потрібно знищити. Тому кидає виклик табу: зрікається землі, яка споконвіку вважалася святинею, годувальницею селян, підтримує любовний зв'язок із двоюрідною сестрою, здійснює братовбиство. Помилковим було й підпорядкування владній Рахірі, виконання будь-яких її наказів. Убивши брата, він не відчув задоволення, свободи, батьки його не стали любити більше, на землі працювати не хотів, а з коханкою взагалі розлучився.

\section{«Камінний хрест»}

\section{Василя Стефаника}

Помилка Івана Дідуха полягає в тому, що він піддався впливу дітей і дружини, збирається емігрувати до Канади в пошуках кращого життя. Повинен був довести своє бажання залишитися тут, де виснажлива праця «зігнула його в дугу», забрала всі сили, дати зрозуміти дітям, що боляче кидати все, набуте тяжкою багаторічною працею, і їхати в нікуди.

\section{«Лісова пісня» Лесі Украӥнки}

Помилка Лукаша полягає в тому, що він піддався впливу матері, яка розлучила його з коханою Мавкою та змусила жити з енергійною і працьовитою Килиною. Слабкодухий юнак не боровся за своє щастя, у результаті чого зробив нещасними всіх: себе, бо не досяг внутрішньої і зовнішньої гармонії; Мавку, яка перетворилася на вербу, а згодом згоріла; Килину, яка так і не віднайшла жіночого щастя, породжують абсурдну ситуацію, відчуження від коханої. Лукаш не скористався шансом бути щасливим із найчеснішою, найніжнішою, найпоетичнішою з усіх жінок - Мавкою, тому за зраду був покараний силами природи (перетворився на вовкулаку). Відроджена лісова красуня не звинувачує коханого, тому силою свого кохання допомагає йому знову стати людиною, повернутися до творчого життя. На мить вони знову разом, проте ілюзія зникає - і він, залишившись самотнім, помирає на морозі.

\section{«Момент» Володимира Винниченка}

Помилка головного героя полягає в тому, що під час нелегального переходу через кордон почувається невпевнено, песимістично. У взаєминах із гордою панночкою Мусею виступає несміливим, млявим. Проте під впливом пристрасті кардинально змінюється: 
пробуджується чоловіче начало, бажання жити, хоча й залишився наодинці з мукою осиротілого щастя, яке спалахнуло на мить і зникло разом із чарівною панною. Йому не варто було відпускати Мусю, а спробувати побудувати 3 нею гармонійну сім'ю.

Висновки. Отже, рефлексія помилок художніх персонажів, а також усвідомлення особистісних недоліків, неправильних думок, поведінкових актів, допоможе учням уникнути типових життєвих труднощів, ефективно розв'язати особистісні проблеми.

Перспективи подальших розвідок у даному напрямі. Дослідити схему трансформації сформованих конструктивних висновків, зроблених у процесі інтерпретації життєвих сценаріїв художніх персонажів, у формі тверджень оптимістичного характеру.

\section{Перелік використаних джерел:}

1. Аспекти дослідження особистісної рефлексії [Електронний ресурс]. - Режим доступу: http://osvita.ua/ vnz/reports/psychology/27617/. - Назва з екрана.

2. Благодир Л. Робота над помилками як одна із форм подолання прогалин у знаннях і вміннях учнів / Л. Благодир // Психолого-педагогічні проблеми сільської школи. - 2009. - Випуск 30. - С. 63 - 69.

3. Курдюк О. О. Помилки та їх види / О. О. Курдюк [Електронний pecypc]. Режим доступу: http:// journlib.univ.kiev.ua/index.php?act=article\&article=1556.

- Назва $з$ екрана.

4. Партико 3. В. Загальне редагування. Нормативні основи: навч. посіб. / 3. В. Партико. - Л. : Афіша, 2001. $-416 \mathrm{c}$.

5. Помилка [Електронний ресурс]. Режим доступу: http://sum.in.ua/s/pomylka. - Назва з екрана.

6. Як визнати власну помилку [Електронний ресурс]. Режим доступу: http://www.secret-press.com/vih11.html. - Назва з екрана.

\section{References (Transliteration):}

1. Aspekty doslidzhennia osobystisnoi refleksii [Elektronnyi resurs]. - Rezhym dostupu: http://osvita.ua/ vnz/reports/psychology/27617/. - Nazva z ekrana.

2. Blagodyr L. Robota nad pomylkamy yak odna iz form podolannia progalyn u znanniah i vminniah uchniv / L. Blagodyr // Psyhologo-pedagogichni problemy silskoi shkoly. - 2009. - Vypusk 30. - S. 63 - 69.

3. Kurdiuk O. O. Pomylky ta yikh vydy / O. O. Kurdiuk [Elektronnyi resurs]. Rezhym dostupu: http:// journlib.univ.kiev.ua/index.php?act=article\&article $=1556$.

- Nazva z ekrana.

4. Partyko Z. V. Zahalne redahuvannia. Normatyvni osnovy: navch. posib. / Z. V. Partyko. - L. : Afisha, 2001. $-416 \mathrm{~s}$.

5. Pomylka [Elektronnyi resurs]. Rezhym dostupu: http:// sum.in.ua/s/pomylka. - Nazva z ekrana.

6. Yak vyznaty vlasnu pomylku [Elektronnyi resurs]. Rezhym dostupu: http://www.secret-press.com/vih11.html. - Nazva z ekrana.

\section{Buturlym Tetiana}

PhD, specialist of higher category, teacher of the Ukrainian language and literature of Nizhyn Pedagogical Lyceum of Chernihiv Regional Council, Nizhyn (Ukraine)

\section{PERCEPTION AND \\ UNDERSTANDING BY PUPILS LIFE MISTAKES OF LITERARY CHARACTERS AS A METHOD OF SELFIMPRUVEMENT}

\section{ABSTRACT}

In the article the problem of necessity of awareness of character's mistakes in fiction as a 
way to self-knowledge, self-perfection of a personality is actualized. It is marked importance to carry out the reflection of own actions, ideas, emotional states. A concept «error» is analysed. Classification of errors is resulted of S. Partiko: informative, modal, actual, temporal, local, situation, semiotics (vidobrazhuval'ni, value, tezaurusni), spriynyattevi, atenciyni, copy. Maintenance of concept «psychological error» is analysed (conscious or bezsvidomi ideas, senses, actions which violate a withstand harmonious connection with own «I» and world, predetermine deep heartfelt sufferings, internal). The examples are given from program works of Ukrainian literature of the $10^{\text {th }}$ form: what exactly the characters did wrong, approximate ways of perfection of the behaviour are outlined. The mistakes of such works are analysed: Mariia and Omelko («Kaidash Family» by I. NechuiLevytskyi), Chipka («Do oxen really roar, when mangers are full?» by Panas Myrnyi and Ivan Bilyk), Martyn («Martyn Borulia» by Ivan Karpenko-Karyi), Dokiia («Drudge» by B. Grinchenko), Moisei («Moisei» by I. Franko), Khoma («Jay’s wing» by I. Franko), protagonist («Intermezzo» by M. Kotsiubynskyi), Ivan («Shadows of forgotten ancestors» by $\mathrm{M}$. Kotsiubynskyi), Sava («Earth» by O. Kobylianska), Ivan («Stone cross» by V. Stefanyk), Lukash («Forest song» by Lesia Ukrainka), protagonist («Moment» by V. Vynnychenko). It was defined how nonconstructive character traits, behaviour, values affect life way of characters. Connection between possibility of a character and a student to make a step to self-development by awareness and correction of mistakes was found.

Key words: reflection, mistakes, fiction characters, awarenesses of problem, selfperfection.

\section{Бутурлим Татьяна Ивановна}

Кандидат педагогических наук, спеичалист выстей категории, учитель украинского языка и литературы Нежинского областного педагогического лищея Черниговского областного совета, г. Нежин (Украина)

\section{ОСОЗНАНИЕ ОШИБОК ХУДОЖЕСТВЕННЫХ ПЕРСОНАЖЕЙ КАК ПУТЬ К САМОСОВЕРШЕНСТВОВАНИЕ УЧАЩИХСЯ}

Аннотация. В статье актуализируется проблема необходимости осознания ошибок персонажей художественных произведений как путь к самопознанию, самоусовершенствованию личности. Отмечено важность осуществлять рефлексию собственных действий, мыслей, эмоциональных состояний. Проанализировано понятие «ошибка». Приведена классификация ошибок 3. Партико: информационные, модальные, фактические, темпоральные, локальные, ситуативные, семиотические (изобразительные, смысловые, тезаурусные), созидательные, атенционные, копировальные. Приведены примеры из программных произведений украинской литературы 10 класса: определенно, что именно неправильно сделали персонажи, очерченно ориентировоч- 
ные пути совершенствования поведения. Проанализированы ошибки таких художественных образов: Маруси и Омелька («Кайдашева семья» И. Нечуя-Левицкого), Чипки («Разве ревут волы, когда ясли полны?» Панаса Мирного и Ивана Билыка), Мартына («Мартын Боруля» Ивана Карпенка-Карого), Докии («Каторжная» Б. Гринченка), Моисей («Моисей» И. Франка), Фома («Крыло сойки» И. Франка), главного героя («Intermezzo» М. Коцюбинского), Ивана («Тени забытых предков» М. Коцюбинского), Савы («Земля» О. Кобылянской), Ивана («Каменный крест» В. Стефаника), Лукаша («Лесная песня» Леси Украинки), главного героя («Момент» В. Винниченко). Определенно, как неконструктивные черты характера, поведение, ценностные ориентации отражаются на жизненном сценарии персонажей. Установлено взаимосвязь между возможностью персонажа и ученика сделать шаг к саморазвитию путем осознания и коррекции ошибок.

Ключевые слова: рефлексия, ошибки, художественные персонажи, осознания проблемы, самоусовершенствование. 